OPEN ACCESS

Edited by:

Simone Brogi,

University of Pisa, Italy

Reviewed by:

Sherif S. Ebada,

Ain Shams University, Egypt

Tung Truong,

University of Pittsburgh, United States

*Correspondence:

Pei Wang

wangpei@itbb.org.cn

Wenli Mei

meiwenli@itbb.org.cn

${ }^{\text {t}}$ These authors have contributed equally to this work

Specialty section: This article was submitted to Medicinal and Pharmaceutical Chemistry, a section of the journal Frontiers in Chemistry

Received: 10 September 2021 Accepted: 22 November 2021 Published: 16 December 2021

Citation:

Cao X, Guo L, Cai C, Kong F, Yuan J,

Gai C, Dai H, Wang $P$ and Mei $W$ (2021) Metabolites From the

Mangrove-Derived Fungus

Cladosporium sp. HNWSW-1.

Front. Chem. 9:773703.

doi: 10.3389/fchem.2021.773703

\section{Metabolites From the Mangrove-Derived Fungus Cladosporium sp. HNWSW-1}

\author{
Xi Cao ${ }^{1,2 \dagger}$, Lei Guo ${ }^{2 \dagger}$, Caihong Cai ${ }^{1}$, Fandong Kong ${ }^{3}$, Jingzhe Yuan ${ }^{1}$, Cuijuan Gai ${ }^{1}$, \\ Haofu Dai ${ }^{1}$, Pei Wang ${ }^{1 *}$ and Wenli Mei ${ }^{1 *}$
}

\begin{abstract}
${ }^{1}$ Hainan Key Laboratory for Research and Development of Natural Products From Li Folk Medicine, Hainan Institute for Tropical Agricultural Resources, Institute of Tropical Bioscience and Biotechnology, Chinese Academy of Tropical Agricultural Sciences, Haikou, China, ${ }^{2}$ Jiangsu Key Laboratory of Marine Bioresources and Environment, Co-Innovation Center of Jiangsu Marine BioIndustry Technology, Jiangsu Ocean University, Lianyungang, China, ${ }^{3}$ Key Laboratory of Chemistry and Engineering of Forest Products, State Ethnic Affairs Commission, Guangxi Key Laboratory of Chemistry and Engineering of Forest Products, Guangxi Collaborative Innovation Center for Chemistry and Engineering of Forest Products, School of Chemistry and Chemical Engineering, Guangxi University for Nationalities, Nanning, China
\end{abstract}

Two new benzoic acids, cladoslide A (1) and cladoslide B (2); one new $\beta$-carboline derivative, cladospomine (3); and one new pyridin-2(1H)-one, cladoslide $C(\mathbf{4})$, were isolated from the fermentation cultures of the mangrove-derived fungus Cladosporium sp. HNWSW-1, along with the previously reported $N$-acetyl- $\beta$-oxotryptamine (5), (4S,5S,11R)-iso-cladospolide B (6), (4S,5S,11S)-iso-cladospolide B (7), and $(4 R, 5 S, 11 R)$-iso-cladospolide B (8). Their structures were elucidated by spectroscopic analysis, $\mathrm{Rh}_{2}\left(\mathrm{OCOCF}_{3}\right)_{4}$-induced ECD experiments, and Marfey's method. Compound $\mathbf{1}$ showed cytotoxicity against the $\mathrm{K} 562$ cell line with $\mathrm{IC}_{50}$ values of $13.10 \pm 0.08 \mu \mathrm{M}$. Moreover, compounds $\mathbf{1}$ and $\mathbf{5}$ exhibited inhibitory activity against $\alpha$-glycosidase with $\mathrm{IC}_{50}$ values of $0.32 \pm 0.01 \mathrm{mM}$ and $0.17 \pm 0.01 \mathrm{mM}$, respectively.

Keywords: mangrove-derived fungus, Cladosporium sp., metabolites, cytotoxicity, a-glycosidase inhibitor

\section{INTRODUCTION}

Mangrove-derived fungi are an important resource for structurally and biologically diverse substances for drug discovery, and in recent years, over 100 new molecules derived from mangrove-derived fungi have been discovered every year (Blunt et al., 2018; Carroll et al., 2019; Carroll et al., 2020). The genus Cladosporium (Cladosporiaceae) is one of the largest genera of dematiaceous hyphomycetes (Bensch et al., 2015). Many novel bioactive natural products were isolated from Cladosporium fungus, such as polyketides (Zhang et al., 2019; Zhu et al., 2018), macrolides (Huang et al., 2019), perylenequinones (Zhang et al., 2020), and indole alkaloids (Peng et al., 2013), which exhibited antimicrobial (Zhang et al., 2019), cytotoxic (Zhu et al., 2018), antiviral (Peng et al., 2013), and quorum-sensing inhibitory activities (Zhang et al., 2020).

As part of our previous research on novel biologically active natural products from mangrovederived fungi, two novel succinimide-containing derivatives, cladosporitins $\mathrm{A}$ and $\mathrm{B}$, have been isolated from the mangrove-derived Cladosporium sp. HNWSW-1 (Wang et al., 2019). Our further chemical investigations on this fungus led to the isolation of two new benzoic acids ( 1 and 2 ), one new $\beta$-carboline derivative (3), and one new pyridin-2(1H)-one (4), along with four known compounds (5-8) (Martínez-Luis et al., 2012; Reddy et al., 2012; Franck et al., 2001) from the EtOAc extract of its fermentation cultures. We describe the isolation, structure elucidation, and biological activities of these compounds in this article. 


\section{MATERIALS AND METHODS}

\section{General Experimental Procedures}

Silica gel (60-80, 200-300 mesh, Qingdao Marine Chemical Co. Ltd.), ODS gel (20-45 m, Fuji Silysia Chemical Co. Ltd.), and Sephadex LH-20 (Merck, Kenilworth, NJ, United States) were used for column chromatography. Optical rotations were measured on a MCP 5100 modular compact polarimeter (Anton Paar, Austria). ECD spectra were recorded on a Bio-Logic Science MOS-500 spectrometer (Biologic, France). UV spectra were measured on a Beckman DU-640 spectrophotometer (Beckman Coulter, Inc., Brea, CA). IR absorptions were obtained on a Nicolet 380 FT-IR instrument (Thermo, Waltham, MA, United States) using $\mathrm{KBr}$ pellets. $1 \mathrm{D}$ and 2D NMR spectra were recorded on a Bruker AV III spectrometer (Bruker, United States; ${ }^{1} \mathrm{H}$ NMR at $500 \mathrm{MHz}$ and ${ }^{13} \mathrm{C}$ NMR at $125 \mathrm{MHz}$ for 1-3 and 5; ${ }^{1} \mathrm{H}$ NMR at $600 \mathrm{MHz}$ and ${ }^{13} \mathrm{C}$ NMR at $150 \mathrm{MHz}$ for 4, 6-8; and HMBC spectrum for 3) using TMS as the internal standard. ESIMS and HRESIMS were recorded with amaZon SL (Bruker, United States) or Compact QqTOF (Bruker, United States). Semipreparative HPLC was carried out using an ODS column and 5PFP column (Cosmosil-pack, $10 \times$ $250 \mathrm{~mm}, 5 \mu \mathrm{m}, 4 \mathrm{ml} / \mathrm{min}$, Nacalai Tesque).

\section{Fungal Material}

The strain of Cladosporium sp. HNWSW-1 was isolated from the healthy tree root of Ceriops tagal, which was collected from the Dong Zhai Gang Mangrove Reserve in Hainan Province in July 2011 (Wang et al., 2019). The fungus was identified based on the DNA sequences (GenBank access No. MH 535968) of the $18 \mathrm{Sr}$ DNA gene (Wang et al., 2019).

\section{Fermentation and Extraction}

Cladosporium sp. HNWSW-1 was cultured in PDB (potato liquid media consisting of $200.0 \mathrm{~g} / \mathrm{L}$ potato, $20.0 \mathrm{~g} / \mathrm{L}$ glucose, and $1000 \mathrm{ml}$ deionized water) at $28^{\circ} \mathrm{C}$ and $150 \mathrm{rpm}$ for $72 \mathrm{~h}$. Then, $5 \mathrm{ml}$ seed broth was transferred to $1000 \mathrm{ml}$ Erlenmeyer flasks (60 flasks) each containing rice medium $(80.0 \mathrm{~g}$ rice, $120.0 \mathrm{ml}$ water, and $120.0 \mathrm{mg}$ tryptophan). The flasks were incubated at room temperature under static conditions for 60 days. The cultures were extracted three times by EtOAc, and the EtOAc solutions were combined and evaporated under reduced pressure to give a dark brown gum $(40.0 \mathrm{~g})$. Then, the extracts were dissolved in $90 \% \mathrm{CH}_{3} \mathrm{OH}$, and the solution was extracted three times by petroleum ether. The methanol and petroleum ether solutions were evaporated under reduced pressure. The crude methanol extract $(20.0 \mathrm{~g})$ was obtained.

\section{Purification and Identification}

The crude methanol extract $(20.0 \mathrm{~g})$ was fractionated into 12 fractions (Fr.1-Fr.12) on a silica gel VLC column eluted with a gradient elution of $\mathrm{CH}_{2} \mathrm{Cl}_{2}$-petroleum ether $(0-100 \%)$ and $\mathrm{MeOH}$ $\mathrm{CH}_{2} \mathrm{Cl}_{2}(0-100 \%)$. Fr.6 (2.4 g) was subjected to an $\mathrm{Rp}-\mathrm{C}_{18}$ silica gel column eluted with a gradient of water-MeOH (10-100\%) to give 25 fractions (Fr.6.1-Fr.6.25). Fr.6.6 (535.0 mg) was further chromatographed on the $\mathrm{Rp}-\mathrm{C}_{18}$ silica gel column using a step gradient with water-MeOH $(10-100 \%)$ to obtain six fractions (Fr.6.6.1-Fr.6.6.6). Fr.6.6.4 (138.0 mg) was purified by a
TABLE 1 | ${ }^{1} \mathrm{H}$ and ${ }^{13} \mathrm{C}$ NMR data for $\mathbf{1}$ and 2 (500 and $125 \mathrm{MHz}, \delta$ in ppm) in $\mathrm{CD}_{3} \mathrm{OD}$.

\begin{tabular}{|c|c|c|c|c|}
\hline \multirow[t]{2}{*}{ No. } & \multicolumn{2}{|r|}{1} & \multicolumn{2}{|r|}{2} \\
\hline & $\delta_{\mathrm{c}}$ & $\begin{array}{c}\delta_{\mathrm{H}}, \text { mult. }(J \mathrm{in} \\
\mathrm{Hz})\end{array}$ & $\delta_{\mathrm{c}}$ & $\begin{array}{c}\delta_{\mathrm{H}}, \text { mult. }(J \mathrm{in} \\
\mathrm{Hz})\end{array}$ \\
\hline 1 & $159.4, \mathrm{C}$ & - & 159.3, C & - \\
\hline 2 & $122.2, \mathrm{C}$ & - & 122.2, C & - \\
\hline 3 & $132.9, \mathrm{CH}$ & $7.80, d,(2.1)$ & $132.9, \mathrm{CH}$ & $7.78, \mathrm{~s}$ \\
\hline 4 & 123.2, C & - & 123.3, C & - \\
\hline 5 & $130.4 \mathrm{CH}$ & $7.75, \mathrm{dd},(8.5,2.1)$ & $130.4, \mathrm{CH}$ & $7.73, d,(8.7)$ \\
\hline 6 & 118.2, $\mathrm{CH}$ & $6.79, \mathrm{~d},(8.5)$ & $118.1, \mathrm{CH}$ & $6.75, d,(8.7)$ \\
\hline 7 & $22.7, \mathrm{CH}_{2}$ & $2.84, \mathrm{~m}$ & $22.7, \mathrm{CH}_{2}$ & $2.84, m$ \\
\hline 8 & $31.7, \mathrm{CH}_{2}$ & $1.85, \mathrm{~m}$ & $31.7, \mathrm{CH}_{2}$ & $1.84, \mathrm{~m}$ \\
\hline 9 & 77.7, C & - & 77.6, C & - \\
\hline \multirow[t]{2}{*}{10} & 36.0, $\mathrm{CH}_{2}$ & 2.01, dt, $(14.7,7.4)$ & $35.9, \mathrm{CH}_{2}$ & $2.03, \mathrm{dt},(14.3,7.8)$ \\
\hline & & $1.93, \mathrm{dt},(14.7,7.9)$ & & $1.94, \mathrm{dt},(14.3,7.9)$ \\
\hline 11 & 29.4, $\mathrm{CH}_{2}$ & $2.46, t,(7.9)$ & 29.3, $\mathrm{CH}_{2}$ & $2.50, \mathrm{t},(7.9)$ \\
\hline 12 & $177.4, \mathrm{C}$ & - & $175.8, \mathrm{C}$ & - \\
\hline 13 & $24.0, \mathrm{CH}_{3}$ & $1.30, \mathrm{~s}$ & 24.0, $\mathrm{CH}_{3}$ & $1.29, \mathrm{~s}$ \\
\hline 14 & 170.1, C & - & 170.1, C & - \\
\hline 15 & - & - & $52.2, \mathrm{OCH}_{3}$ & $3.65, s$ \\
\hline
\end{tabular}

Sephadex LH-20 column and eluted with $\mathrm{MeOH}$ to give three fractions (Fr.6.6.4.1-Fr.6.6.4.3). Fr.6.6.4.1 was submitted to HPLC purification on a $5 \mathrm{PFP}$ column eluted with $15 \% \mathrm{ACN}$ ( $85 \%$ water added to $0.05 \%$ trifluoroacetic acid) to yield $7\left(11.0 \mathrm{mg}, \mathrm{t}_{R}\right.$ $10.30 \mathrm{~min})$ and $8\left(4.7 \mathrm{mg}, \mathrm{t}_{R} 13.20 \mathrm{~min}\right)$. Fr.6.10 (34.0 mg) was purified by a Sephadex LH-20 column and eluted with $\mathrm{MeOH}$ to yield 1 ( $4.0 \mathrm{mg})$. Fr.7 $\left(853.1 \mathrm{mg}\right.$ ) was submitted to an $\mathrm{RP}-\mathrm{C}_{18}$ column and eluted with $\mathrm{MeOH}$-water to give 30 fractions (Fr.7.1-Fr.7.30). Fr.7.5 (110.2 mg) was separated by a Sephadex LH-20 column and eluted with $\mathrm{MeOH}$ to give four fractions (Fr.7.5.1-Fr.7.5.4). Fr.7.5.1 (32.0 mg) was submitted to HPLC purification on a 5PFP column eluted with $30 \% \mathrm{MeOH}(70 \%$ water added to $0.05 \%$ trifluoroacetic acid) to yield $6\left(12.0 \mathrm{mg}\right.$, $\mathrm{t}_{R}$ 23.0 min). Fr.7.12 (45.9 mg) was separated by a Sephadex LH-20 column and eluted with $\mathrm{MeOH}$ to give 5 fractions (Fr.7.12.1-Fr.7.12.5). Fr.7.12.5 was submitted to HPLC purification on a $5 \mathrm{PFP}$ column eluted with $50 \% \mathrm{MeOH}(50 \%$ water added to $0.05 \%$ trifluoroacetic acid) to yield $\mathbf{5}\left(3.8 \mathrm{mg}\right.$, $\mathrm{t}_{R}$ $27.0 \mathrm{~min}$ ). Fr.7.13 (36.4 mg) was also separated by a Sephadex LH20 column and eluted with $\mathrm{MeOH}$ to give eight fractions (Fr.7.13.1-Fr.7.13.8). Fr.7.13.6 was submitted to HPLC purification on a 5PFP column eluted with $40 \% \mathrm{MeOH}(60 \%$ water added to $0.05 \%$ trifluoroacetic acid) to yield $4\left(1.0 \mathrm{mg}, \mathrm{t}_{R}\right.$ 27.0 min). Fr.7.18 (34.2 mg) was separated by a Sephadex LH-20 column and eluted with $\mathrm{MeOH}$ to give five fractions (Fr.7.18.1-Fr.7.18.5). Fr.7.18.3 was submitted to HPLC purification on a 5PFP column eluted with $50 \% \mathrm{MeOH}(50 \%$ water added to $0.05 \%$ trifluoroacetic acid) to yield $2\left(2.0 \mathrm{mg}, \mathrm{t}_{R}\right.$ $16.9 \mathrm{~min})$. Fr.7.20 was submitted to HPLC purification on a 5PFP column eluted with $30 \% \mathrm{MeCN}$ (70\% water added to $0.05 \%$ trifluoroacetic acid) to yield $3\left(2.0 \mathrm{mg}, \mathrm{t}_{R} 24.6 \mathrm{~min}\right)$.

\section{Characterization of Compounds 1-4}

Cladoslide A (1): yellow, amorphous powder; $[\alpha]_{\mathrm{D}}^{20}+26.5(c 0.2$, $\mathrm{MeOH}) ; \mathrm{UV}(\mathrm{MeOH}) \lambda_{\max }(\log \varepsilon) 259$ (5.39) and 205 (5.42) nm; 
TABLE $2 \mid{ }^{1} \mathrm{H}$ and ${ }^{13} \mathrm{C}$ NMR data for 3 (500 and $125 \mathrm{MHz}, \delta$ in ppm) in DMSO and 4 (600 and $150 \mathrm{MHz}, \delta$ in ppm) in $\mathrm{CD}_{3} \mathrm{OD}$.
No.

\begin{tabular}{|c|c|}
\hline & 3 \\
\hline$\delta_{\mathrm{C}}$ & $\begin{array}{c}\delta_{\mathrm{H}} \text {, mult. ( } \boldsymbol{J} \text { in } \\
\mathrm{Hz})\end{array}$ \\
\hline
\end{tabular}

142.3, $\mathrm{C}^{\mathrm{a}}$

131.0, $\mathrm{C}^{\mathrm{a}}$

$119.8, \mathrm{CH}$

$122.8, \mathrm{CH}$

$121.2, \mathrm{CH}$

129.9, $\mathrm{CH}$

113.9, $\mathrm{CH}$

136.5, C

132.2, C

120.7, C

142.7, C

165.2, C

$50.9, \mathrm{CH}$

174.6, C

40.6, $\mathrm{CH}_{2}$

25.0, $\mathrm{CH}$

23.5, $\mathrm{CH}_{3}$

$21.8, \mathrm{CH}_{3}$

166.2, C

8.47, d, (7.8)

7.35, t, (7.8)

7.64, t, (7.8)

7.85, d, (8.1)

$\mathrm{NH}, 12.22$, s

$\mathrm{NH}, 9.59, \mathrm{~s}$

4.69, t, (6.40)

$1.87, \mathrm{~m}, 1.77, \mathrm{~m}$

1.76, $\mathrm{m}$

$0.98, d,(6.0)$

0.96, d, (5.9)

4
$\delta_{\mathrm{C}} \quad \delta_{\mathrm{H}}, \underset{\mathrm{Hz})}{\text { mult. }(J \text { in }}$

163.3, $\mathrm{C}^{\mathrm{a}}$

117.8, $\mathrm{CH}$

153.2, C

109.8, CH

$137.4, \mathrm{CH}$

48.4, $\mathrm{CH}_{2}$

24.2, $\mathrm{CH}_{2}$

$30.2, \mathrm{CH}_{2}$

174.9, C

19.8, $\mathrm{CH}_{3}$
${ }^{a}$ Assigned from HMBC and HSQC spectra.

IR (KBr) $v_{\max }: 3247,2941,1700,1610,1261$, and $1161 \mathrm{~cm}^{-1}$; HRESIMS m/z $305.1006[\mathrm{M}+\mathrm{Na}]^{+}$(calcd. for $\mathrm{C}_{14} \mathrm{H}_{18} \mathrm{O}_{6} \mathrm{Na}$ : 305.0996); ${ }^{1} \mathrm{H}$ and ${ }^{13} \mathrm{C}$ NMR data (see Table 1).

Cladoslide B (2): yellow oil; $[\alpha]_{\mathrm{D}}^{20}+6$ (c 0.04, MeOH); UV $(\mathrm{MeOH}) \lambda_{\max }(\log \varepsilon) 259$ (5.46) and $205(5.44) \mathrm{nm}$; IR (KBr) $v_{\max }$ : 3394, 2937, 1722, 1613, 1260, and $1186 \mathrm{~cm}^{-1}$; HRESIMS $\mathrm{m} / \mathrm{z}$ $319.1139[\mathrm{M}+\mathrm{Na}]^{+}$(calcd. for $\mathrm{C}_{15} \mathrm{H}_{20} \mathrm{O}_{6} \mathrm{Na}$ : 319.1152); ${ }^{1} \mathrm{H}$ and

${ }^{13} \mathrm{C}$ NMR data (see Table 1 ).

Cladospomine (3): yellow, amorphous powder; $[\alpha]_{\mathrm{D}}^{20}-4(c$ $0.2, \mathrm{MeOH}) ; \mathrm{UV}(\mathrm{MeOH}) \lambda_{\max }(\log \varepsilon) 362$ (4.53), 279 (5.28), and 217 (5.18) nm; IR (KBr) $v_{\text {max }}$ : 3341, 2958, 1721, 1653, 1531, 1366 , and $1235 \mathrm{~cm}^{-1}$; HRESIMS $m / z 392.1227[\mathrm{M}+\mathrm{Na}]^{+}$(calcd. for $\mathrm{C}_{19} \mathrm{H}_{19} \mathrm{~N}_{3} \mathrm{O}_{5} \mathrm{Na}$ : 392.1217); ${ }^{1} \mathrm{H}$ and ${ }^{13} \mathrm{C}$ NMR data (see Table 2).
Cladoslide C (4): yellow oil; UV (MeOH) $\lambda_{\max }(\log \varepsilon) 297$ (4.68), 229 (4.72), and 203 (5.08) nm; IR (KBr) $\nu_{\max }$ : 3421, 2955, $1724,1656,1570$, and $1196 \mathrm{~cm}^{-1}$; HRESIMS $m / z 218.0779[\mathrm{M}+$ $\mathrm{Na}]^{+}$(calcd. for $\mathrm{C}_{10} \mathrm{H}_{13} \mathrm{NO}_{3} \mathrm{Na}: 218.0788$ ); ${ }^{1} \mathrm{H}$ and ${ }^{13} \mathrm{C} \mathrm{NMR}$ data (see Table 2).

\section{$\mathrm{Rh}_{2}\left(\mathrm{OCOCF}_{3}\right)_{4}$-Induced ECD Experiments of 1 and 2}

The samples of compounds $\mathbf{1}$ and $\mathbf{2}(0.1 \mathrm{mg})$ were dissolved in a dry solution of the stock $\left[\mathrm{Rh}_{2}\left(\mathrm{OCOCF}_{3}\right)_{4}\right]$ complex $(1.5 \mathrm{mg})$ in $\mathrm{CH}_{2} \mathrm{Cl}_{2}(1 \mathrm{ml})$. The first induced ECD spectra of the compounds were recorded immediately after mixing, and their time evolution was monitored until stationary (about $10 \mathrm{~min}$ after mixing) (Frelek and Szczepek, 1999). The inherent ECD spectra were subtracted. The absolute configurations of the C-9 tertiary alcohol in $\mathbf{1}$ and $\mathbf{2}$ were identified by the observed sign of the E-band at ca. $350 \mathrm{~nm}$ in the induced ECD spectra (Gerards and Snatzke, 1990; Frelek and Szczepek, 1999).

\section{Preparation of FDAA Derivatives of the Acid Hydrolysate of 3 and the Derivatives of Two Authentic Leucine Samples (L- and D-) and Marfey's Analysis}

Compound $3(1.0 \mathrm{mg}, 2.71 \mu \mathrm{mol})$ was dissolved in $6 \mathrm{M} \mathrm{HCl}$ $(1 \mathrm{ml})$ in a sealed tube, and the mixture was heated at $105^{\circ} \mathrm{C}$ for $11 \mathrm{~h}$. Then, the solution was cooled and evaporated to dryness. The residue was dissolved in $\mathrm{H}_{2} \mathrm{O}(250 \mu \mathrm{l})$. Meanwhile, L-Leu and D-Leu were also dissolved in $\mathrm{H}_{2} \mathrm{O}$ ( $50 \mathrm{mM}$ each), and $50 \mu \mathrm{l}$ of each solution was treated with $200 \mu \mathrm{l}$ of $1 \%$ FDAA in acetone followed by $1.0 \mathrm{M} \mathrm{NaHCO}_{3}(40 \mu \mathrm{l})$. The reaction was maintained for $1 \mathrm{~h}$ at $45^{\circ} \mathrm{C}$ and then quenched by the addition of $2.0 \mathrm{M} \mathrm{HCl}(10 \mu \mathrm{l})$. The corresponding FDAA derivatives of the hydrolysate of 3, L- Leu, and D-Leu were analyzed by HPLC on an ODS column maintained at $30{ }^{\circ} \mathrm{C}$ using the following programs: solvent $\mathrm{A}$, $\mathrm{H}_{2} \mathrm{O}+0.1 \%$ TFA; solvent $\mathrm{B}, \mathrm{MeCN}$; linear gradient, 0 min $25 \% \mathrm{~B}$ (75\% A), $40 \mathrm{~min} 60 \% \mathrm{~B}(40 \% \mathrm{~A})$, and $45 \mathrm{~min} 100 \% \mathrm{~B}$; UV detection at $340 \mathrm{~nm}$. The retention times for the FDAA derivatives of the hydrolysate of 3, L-Leu, and D-Leu were 24.28, 24.28, and $28.59 \mathrm{~min}$, respectively (Marfey, 1984).

TABLE $\mathbf{3} \mid$ IC $\mathrm{C}_{50}$ values of cytotoxicity and $\alpha$-glycosidase inhibitory activity of compounds $\mathbf{1 - 3}$ and $\mathbf{5 - 8}$.

\begin{tabular}{|c|c|c|c|c|c|}
\hline \multirow[t]{2}{*}{ Compounds } & \multicolumn{4}{|c|}{$\mathrm{IC}_{50}(\mu \mathrm{M})$} & \multirow{2}{*}{$\frac{\mathrm{IC}_{50}(\mathrm{mM})}{\text { a-Glycosidase }}$} \\
\hline & Hela & BEL-7042 & K562 & SGC-7901 & \\
\hline 1 & $>100$ & $>100$ & $13.10 \pm 0.08$ & $>100$ & $0.32 \pm 0.01$ \\
\hline 3 & $>100$ & $>100$ & $>100$ & $>100$ & $>1.0$ \\
\hline 5 & $>100$ & $>100$ & $>100$ & $>100$ & $0.17 \pm 0.01$ \\
\hline 6 & $>100$ & $>100$ & $>100$ & $>100$ & $>1.0$ \\
\hline 7 & $>100$ & $>100$ & $>100$ & $>100$ & $>1.0$ \\
\hline Acarbose & $N D^{a}$ & $N D^{a}$ & $N D^{a}$ & $N D^{a}$ & $0.72 \pm 0.01$ \\
\hline
\end{tabular}

${ }^{a}$ Not detected. 


\section{Bioassay for Cytotoxicity}

The cytotoxic activity of compounds 1-3 and 5-8 against human cervical cancer cell lines (Hela), human hepatic carcinoma cell lines (BEL-7402), leukemia cell lines (K562), and human gastric cell lines (SGC-7901) was assayed by the MTT method (Mosmann, 1983; Wang et al., 2013). These cell lines were purchased from Shang Hai Cell Bank of Chinese Academy of Sciences. Hela, BEL-7402, K562, and SGC-7901 cell lines were cultured in RPMI-1640 with 10\% FBS under a humidified atmosphere of $5 \% \mathrm{CO}_{2}$ and $95 \%$ air at $37^{\circ} \mathrm{C}$, and $198 \mu \mathrm{l}$ of the cell suspension was plated in 96-well microtiter plates. After being incubated for $24 \mathrm{~h}, 2 \mu \mathrm{l}$ of the test solutions in DMSO was added to each well and further incubated for $36 \mathrm{~h}$. The MTT solution $(20 \mu \mathrm{l}, 5 \mathrm{mg} / \mathrm{ml}$ in IPMI-1640 medium) was then added to each well and further incubated for $4 \mathrm{~h}$. Finally, the medium containing MTT $(150 \mu \mathrm{l})$ was gently replaced by DMSO and pipetted to dissolve any formazan crystals formed. Absorbance was then determined on a Multiskan FC photometric microplate reader (Thermo Fisher Scientific) at $570 \mathrm{~nm}$. Adriamycin was used as the positive control drug.

\section{Bioassay for a-Glycosidase Inhibitory Activity}

a-Glucosidase inhibitory activity of compounds $\mathbf{1 - 3}$ and 5-8 was evaluated according to the literature experimental method ( $\mathrm{Ma}$ et al., 2014). A mixture including $25 \mu \mathrm{l}$ of different compounds (final concentrations of $0.0625,0.125,0.25,0.5$, and $1.0 \mathrm{mM}$ ), $25 \mu \mathrm{l}$ of $\alpha$-glucosidase $(0.2 \mathrm{U} / \mathrm{ml}$, from baker's yeast, Sigma $)$, and $175 \mu$ phosphate buffer ( $\mathrm{pH}$ 6.8) was left to stand for $10 \mathrm{~min}$ at room temperature in a 96 -well plate, and then $25 \mu \mathrm{l}$ of $23.2 \mathrm{mM}$ $p$-nitrophenyl $\alpha$-D-glucopyranoside (Sigma-Aldrich) was added and further incubated at $37^{\circ} \mathrm{C}$ for $15 \mathrm{~min}$. Finally, the absorbance was measured at $405 \mathrm{~nm}$ to determine the amount of p-nitrophenol cleaved by the enzyme using a Synergy H1 Hybrid Multi-Mode Microplate Reader (BioTek Instruments, Inc.). The control was prepared by adding phosphate buffer instead of the sample in the same way as the test. The blank was prepared by adding phosphate buffer instead of $\alpha$-glucosidase using the same method. The inhibition rates $(\%)=\left[\left(\mathrm{OD}_{\text {control }}-\right.\right.$ $\left.\left.\mathrm{OD}_{\text {control blank }}\right)-\left(\mathrm{OD}_{\text {sample }}-\mathrm{OD}_{\text {sample blank }}\right)\right] /\left(\mathrm{OD}_{\text {control }}\right.$ $\left.\mathrm{OD}_{\text {control blank }}\right) \times 100 \%$. Acarbose was used as the positive control with an $\mathrm{IC}_{50}$ value of $0.72 \pm 0.01 \mathrm{mM}$.

\section{RESULTS AND DISCUSSION}

\section{Identification of Compounds 1-4}

Compound $\mathbf{1}$ was isolated as a yellow amorphous powder with the molecular formula of $\mathrm{C}_{14} \mathrm{H}_{18} \mathrm{O}_{6}$ established by HRESIMS $[\mathrm{m} / \mathrm{z}$ $\left.305.1006(\mathrm{M}+\mathrm{Na})^{+}\right]$. The analysis of its ${ }^{1} \mathrm{H},{ }^{13} \mathrm{C}$, and HSQC NMR spectra (see Supplementary Figures S1-S3 in the Supplementary Material) revealed the presence of six aromatic carbons (three of which were protonated), four methylene groups, one methyl group $\left(\delta_{\mathrm{C} / \mathrm{H}} 24.0 / 1.30\right)$, one oxygenated quaternary carbon $\left(\delta_{\mathrm{C}} 77.7\right)$, and two carboxylic carbons $\left(\delta_{\mathrm{C}} 177.4\right.$ and 170.1). These data combined with the molecular formula suggested four unobserved exchangeable protons, which plus the above data accounted for all the ${ }^{1} \mathrm{H}$ and ${ }^{13} \mathrm{C}$ NMR resonances for $\mathbf{1}$. The hydroxyl groups were located at C-1, C-9, C-12, and C-14 by default supported by the chemical shift values for C-1 $\left(\delta_{\mathrm{C}} 159.4\right)$, C-9 $\left(\delta_{\mathrm{C}} 77.7\right), \mathrm{C}-12\left(\delta_{\mathrm{C}} 177.4\right)$, and $\mathrm{C}-14\left(\delta_{\mathrm{C}} 170.1\right)$. The ${ }^{1} \mathrm{H}-{ }^{1} \mathrm{H}$ coupling patterns for the three aromatic protons, $\mathrm{H}-3$ at $\delta_{\mathrm{H}} 7.80(1 \mathrm{H}, \mathrm{d}, J=2.1$ $\mathrm{Hz}), \mathrm{H}-5$ at $\delta_{\mathrm{H}} 7.75(1 \mathrm{H}, \mathrm{dd}, J=8.5,2.1 \mathrm{~Hz})$, and $\mathrm{H}-6$ at $\delta_{\mathrm{H}} 6.79(1 \mathrm{H}$, $\mathrm{d}, J=8.5 \mathrm{~Hz}$ ), suggested the presence of a 1,2,4-trisubstituted benzene ring, which was confirmed by relevant ${ }^{1} \mathrm{H}-{ }^{1} \mathrm{H}$ COSY and HMBC correlations (Figure 2). The HMBC correlation from $\mathrm{H}-3$ and $\mathrm{H}-5$ to C-14 suggested a carboxylic carbon C-14 attached to C-4 $\left(\delta_{\mathrm{C}} 123.2\right)$ directly. The COSY correlations (in Figure 2) from $\mathrm{H}_{2}-7\left(\delta_{\mathrm{H}} 2.84\right)$ to $\mathrm{H}_{2}-8\left(\delta_{\mathrm{H}} 1.85\right)$ and from $\mathrm{H}_{2}-10\left(\delta_{\mathrm{H}} 2.01,1.93\right)$ to $\mathrm{H}_{2}-11\left(\delta_{\mathrm{H}} 2.46\right)$, along with the key HMBC correlations (in Figure 2) from $\mathrm{H}_{2}-10$ to C-8 $\left(\delta_{\mathrm{C}} 31.7\right)$, from $\mathrm{H}_{2}-10$ and $\mathrm{H}_{2}-11$ to $\mathrm{C}-12$, and from $\mathrm{H}_{3}-13\left(\delta_{\mathrm{H}}\right.$ $1.30)$ to $\mathrm{C}-8, \mathrm{C}-9$, and $\mathrm{C}-10\left(\delta_{\mathrm{C}} 36.0\right)$, indicated a 4-hydroxy-4methylhexanoic acid fragment. The above two fragments were connected by the key HMBC correlations from $\mathrm{H}_{2}-8$ to $\mathrm{C}-2\left(\delta_{\mathrm{C}}\right.$ 122.2) and from $\mathrm{H}_{2}-7$ to $\mathrm{C}-1$ and $\mathrm{C}-3\left(\delta_{\mathrm{C}} 132.9\right)$. Thus, the planar structure of 1 was determined as shown in Figure 1, and it was named as cladoslide $\mathrm{A}$. An $\mathrm{Rh}_{2}\left(\mathrm{OCOCF}_{3}\right)_{4}$-induced electronic circular dichrosim (ECD) experiment (Frelek and Szczepek, 1999) was conducted in order to determine the absolute configuration of the C-9 chiral tertiary alcohol. The induced negative Cotton effect at approximately $350 \mathrm{~nm}$ (Figure 3 ) suggested the $9 S$ configuration of 1 based on the bulkiness rule (Gerards and Snatzke, 1990; Frelek and Szczepek, 1999).

Compound 2 was isolated as a yellow oil, whose molecular formula was determined as $\mathrm{C}_{15} \mathrm{H}_{20} \mathrm{O}_{6}$ by HRESIMS $[\mathrm{m} / \mathrm{z}$ $\left.319.1139(\mathrm{M}+\mathrm{Na})^{+}\right]$. A detailed comparison of 1D NMR data of $\mathbf{2}$ (Table $\mathbf{1}$ ) with those of $\mathbf{1}$ indicated that $\mathbf{2}$ has a very similar chemical structure to that of $\mathbf{1}$. The only difference between them was that the carboxyl group attached to C-11 in $\mathbf{1}$ was replaced by a carbomethoxy group in 2 , as evidenced by the presence of a methoxyl group $\left(\delta_{\mathrm{C} / \mathrm{H}}\right.$ 52.2/3.65) in ${ }^{1} \mathrm{H}$ and ${ }^{13} \mathrm{C}$ NMR spectra of 2 and their difference of the molecular formula, along with the key HMBC correlations (in Figure 2) from $\mathrm{H}-10\left(\delta_{\mathrm{H}} 2.03 / 1.94\right), \mathrm{H}-11\left(\delta_{\mathrm{H}} 2.50\right)$, and $\mathrm{H}_{3}-15$ $\left(\delta_{\mathrm{H}} 3.65\right)$ to $\mathrm{C}-12\left(\delta_{\mathrm{C}} 175.8\right)$. Therefore, the planar chemical structure of $\mathbf{2}$ was elucidated as shown in Figure $\mathbf{1}$ and named as cladoslide B. The $9 S$ configuration of $\mathbf{2}$ was also determined according to an induced negative Cotton effect at approximately $350 \mathrm{~nm}$ (Figure 3) by an $\mathrm{Rh}_{2}\left(\mathrm{OCOCF}_{3}\right)_{4}$-induced ECD experiment (Gerards and Snatzke, 1990; Frelek and Szczepek, 1999).

Compound 3 was obtained as a yellow amorphous powder, and it displayed a positive response toward Dragendorff s reagent. Its molecular formula was assigned as $\mathrm{C}_{19} \mathrm{H}_{19} \mathrm{~N}_{3} \mathrm{O}_{5}$ by HRESIMS $\left[m / z 392.1227(\mathrm{M}+\mathrm{Na})^{+}\right]$. The UV spectrum of 3 displayed the characteristic absorption maxima of $\beta$-carboline chromophore at 362, 278, and $217 \mathrm{~nm}$ (Chen et al., 2010; Cao et al., 2012). Interpretation of the ${ }^{1} \mathrm{H}$ NMR, ${ }^{13} \mathrm{C} \mathrm{NMR}$, and HSQC spectroscopic data of 3 (Table 2) displayed resonances for two exchangeable protons $\left(\delta_{\mathrm{H}} 12.2\right.$ and 9.59), eleven aromatic carbons (five of which were protonated), two methyl groups $\left(\delta_{\mathrm{C} / \mathrm{H}} \quad 23.5 / 0.98\right.$ and $\left.\delta_{\mathrm{C} / \mathrm{H}} \quad 21.8 / 0.96\right)$, one methylene group $\left(\delta_{\mathrm{C} / \mathrm{H}} 40.69 / 1.87,1.77\right)$, two $\mathrm{sp}^{3}$ methine groups (one of which was heteroatom-bonded at $\delta_{\mathrm{H} / \mathrm{C}} 4.69 /$ $50.9)$, and three carboxyl or amide carbonyls $\left(\delta_{\mathrm{C}} 174.6,166.2\right.$, 
<smiles>COC(=O)CCC(C)(O)CCc1cc(C(=O)O)ccc1O</smiles><smiles>O=C(O)CCCn1ccc(I)cc1=O</smiles><smiles>CC(=O)NCC(=O)c1c[nH]c2ccccc12</smiles>

4

5<smiles>CC(O)CCCCC[C@H](O)C1C=CC(=O)O1</smiles>

6<smiles>C[C@H](O)CCCCCC[C@H](O)C1C=CC(=O)O1</smiles>

7<smiles>CC(O)CCCCC[C@H](O)[C@H]1C=CC(=O)O1</smiles>

8

FIGURE 1 | Structures of compounds 1-8.

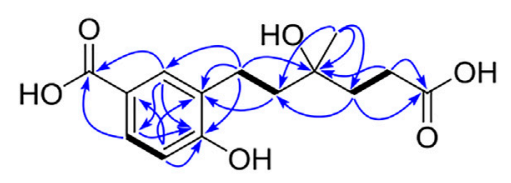

1

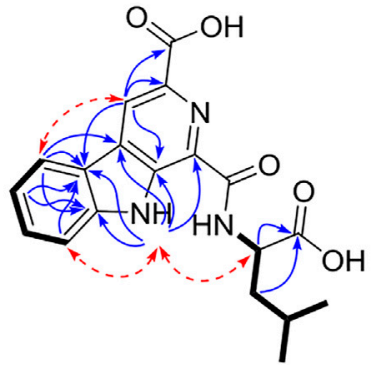

3

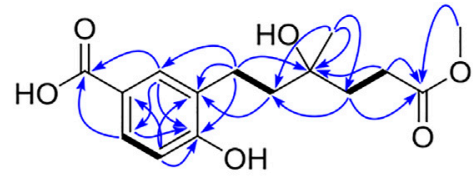

2

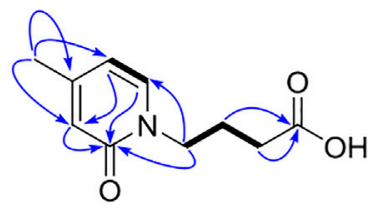

4

FIGURE 2 | Key $\operatorname{HMBC}(\rightarrow),{ }^{1} \mathrm{H}-{ }^{1} \mathrm{H}$ COSY $(-)$, and ROESY $(\leftarrow-\rightarrow)$ correlations of compounds 1-4.

and 165.2). These data and the two unobserved exchangeable protons accounted for all the ${ }^{1} \mathrm{H}$ and ${ }^{13} \mathrm{C}$ NMR resonances for 3 . The ${ }^{1} \mathrm{H}$ NMR spectra of $\mathbf{3}$ exhibited vicinally coupled aromatic proton signals at $\delta_{\mathrm{H}} 8.47(1 \mathrm{H}, \mathrm{d}, J=7.8 \mathrm{~Hz}, \mathrm{H}-5), 7.85(1 \mathrm{H}, \mathrm{d}, J=$ $8.1 \mathrm{~Hz}, \mathrm{H}-8), 7.64(1 \mathrm{H}, \mathrm{t}, J=7.8 \mathrm{~Hz}, \mathrm{H}-7)$, and $7.35(1 \mathrm{H}, \mathrm{t}, J=7.8$
$\mathrm{Hz}, \mathrm{H}-6)$, which combined with the sequential COSY correlations of $\mathrm{H}-5 / \mathrm{H}-6 / \mathrm{H}-7 / \mathrm{H}-8$ were indicative of a $1,2-$ disubstituted benzene ring of $\beta$-carboline alkaloid (Chen et al., 2010; Cao et al., 2012). A downfield aromatic proton singlet at $\delta_{\mathrm{H}} 9.14$ (s) was assigned as the characteristic H-4 

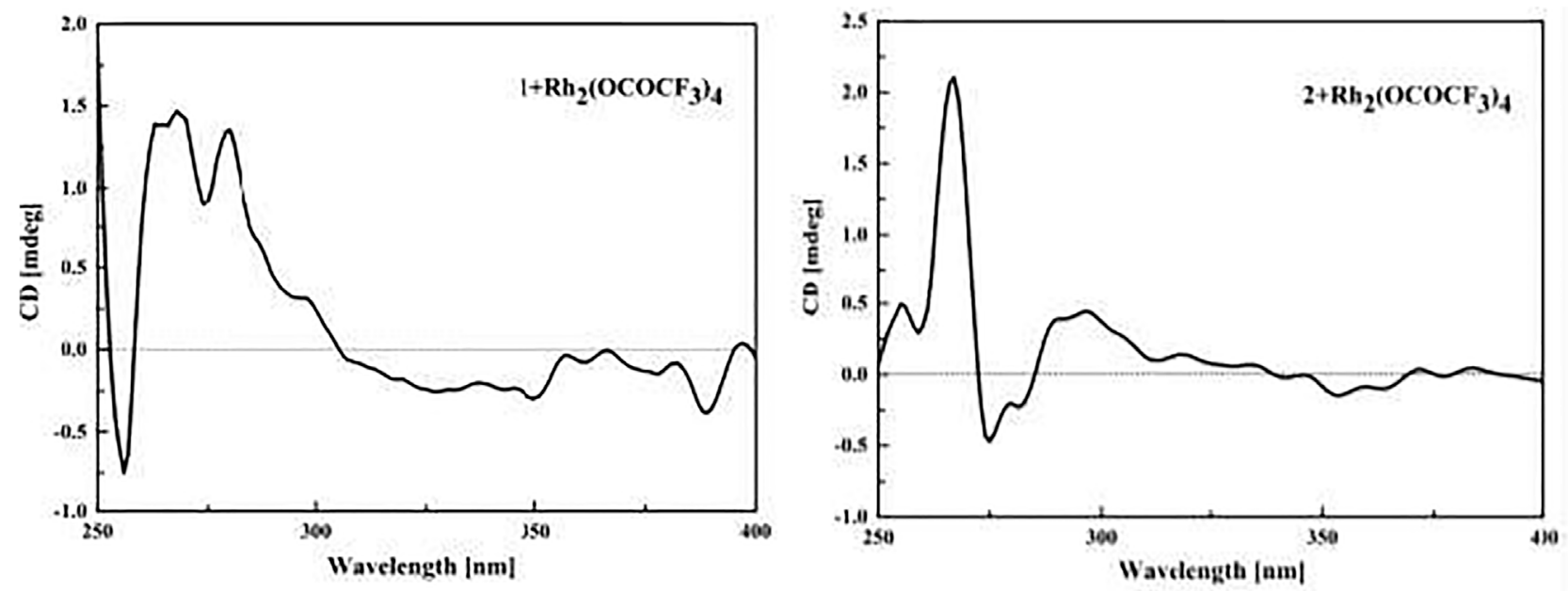

FIGURE $\mathbf{3}$ | ECD spectra of the Rh complex of $\mathbf{1}$ and $\mathbf{2}$ with the inherent ECD spectra subtracted.

proton signal of the $\beta$-carboline alkaloid, evidenced by its ROESY correlation with $\mathrm{H}-5$. The above signals, together with HMBC correlations from H-4 to C-10 $\left(\delta_{\mathrm{C}} 136.5\right)$ and C$12\left(\delta_{\mathrm{C}} 120.7\right)$, from $\mathrm{H}-5$ to $\mathrm{C}-11\left(\delta_{\mathrm{C}} 132.2\right)$ and C-12, from $\mathrm{H}-$ 6 and $\mathrm{H}-8$ to $\mathrm{C}-12$, from $\mathrm{H}-5$ and $\mathrm{H}-7$ to $\mathrm{C}-13\left(\delta_{\mathrm{C}} 142.7\right)$, and from $9-\mathrm{NH}\left(\delta_{\mathrm{H}} 12.22\right)$ to $\mathrm{C}-1\left(\delta_{\mathrm{C}} 142.3\right), \mathrm{C}-10, \mathrm{C}-11$, and C12 , suggested the presence of a $\beta$-carboline skeleton (Chen et al., 2010; Cao et al., 2012). A comparison of the ${ }^{1} \mathrm{H}$ and ${ }^{13} \mathrm{C}$ NMR data for 3 (Table 2) with those of the previously reported dichotomine $\mathrm{H}$ (Cao et al., 2012) suggested that 3 has a very similar chemical structure to that of dichotomine $\mathrm{H}$ (Cao et al., 2012). The main structural difference between them was that the glutamic acid unit in dichotomine $\mathrm{H}$ was replaced by leucine in 3 , as evidenced by the sequential COSY correlations of $\mathrm{H}-15\left(\mathrm{NH}, \delta_{\mathrm{H}} 9.59\right) / \mathrm{H}-16\left(\delta_{\mathrm{H}} 4.69\right) / \mathrm{H}_{2}-18\left(\delta_{\mathrm{H}}\right.$ $1.87,1.77) / \mathrm{H}-19\left(\delta_{\mathrm{H}} 1.76\right), \mathrm{H}-20\left(\delta_{\mathrm{H}} 0.98\right) / \mathrm{H}-19$, and $\mathrm{H}-21$ $\left(\delta_{\mathrm{H}} 0.96\right) / \mathrm{H}-19$, together with $\mathrm{HMBC}$ correlations from $\mathrm{H}_{2}-$ 18 and $\mathrm{H}-16$ to $\mathrm{C}-17\left(\delta_{\mathrm{C}} 174.6\right)$. Moreover, the leucine unit was connected to $\mathrm{C}-14\left(\delta_{\mathrm{C}} 165.2\right)$ rather than C-22 $\left(\delta_{\mathrm{C}} 166.2\right)$ on the basis of the obvious ROESY correlations between 9 $\mathrm{NH}\left(\delta_{\mathrm{H}} 12.22\right)$ and $\mathrm{H}-16\left(\delta_{\mathrm{H}} 4.69\right)$. A carboxyl group (C-22) was attached to $\mathrm{C}-3\left(\delta_{\mathrm{C}} 131.0\right)$ in 3 according to the key $\mathrm{HMBC}$ correlation from $\mathrm{H}-4$ to $\mathrm{C}-3$ and C-22 combined with the molecular formula. The absolute configuration of the leucine was identified as L-leucine by Marfey's method (Marfey, 1984). The mixture obtained after hydrolyzing compound 3 and further derivatization with L-FDAA was analyzed by HPLC-DAD. The derivatives of two authentic leucine samples (L- and D-) were also prepared and analyzed by HPLC-DAD (see Supplementary Figure S26 in Supplementary Material). The chromatogram of the derivative of $\mathbf{3}$ displayed the peak with the retention time $\left(\mathrm{t}_{R} 24.28 \mathrm{~min}\right)$, which was consistent with the retention time and the UV spectra obtained for the derivative of L-Leu $\left(\mathrm{t}_{R}\right.$ $24.28 \mathrm{~min}$ ) and different from the retention time obtained for the derivative of $\mathrm{D}$-Leu $\left(\mathrm{t}_{R} 28.59 \mathrm{~min}\right)$. Finally, the leucine moiety in $\mathbf{3}$ was unambiguously identified as L-Leu, and the structure of compound 3 was elucidated as shown in Figure 1, which was named cladospomine.

Compound 4 was obtained as a yellow oil and possessed a molecular formula $\mathrm{C}_{10} \mathrm{H}_{13} \mathrm{NO}_{3}$ based on a prominent sodium adduct ion peak at $m / z 218.0779[\mathrm{M}+\mathrm{Na}]^{+}$in the HRESIMS spectrum. Its ${ }^{1} \mathrm{H}$, DEPTQ, and HSQC NMR spectra (see Supplementary Figures S20-S22 in Supplementary Material) showed signals for three $\mathrm{sp}^{2}$ methine groups $\left(\delta_{\mathrm{C} / \mathrm{H}} 109.8 / 6.31\right.$, $\delta_{\mathrm{C} / \mathrm{H}} 137.4 / 7.53$, and $\left.\delta_{\mathrm{C} / \mathrm{H}} 117.8 / 6.40\right)$, three methylene groups $\left(\delta_{\mathrm{C} / \mathrm{H}} 48.4 / 4.03, \delta_{\mathrm{C} / \mathrm{H}} 24.2 / 2.03\right.$, and $\left.\delta_{\mathrm{C} / \mathrm{H}} 30.2 / 2.36\right)$, one methyl group $\left(\delta_{\mathrm{C} / \mathrm{H}} 19.8 / 2.25\right)$, one amide carbonyl signal $\left(\delta_{\mathrm{C}} 163.3\right)$, one carboxyl carbonyl signal $\left(\delta_{\mathrm{C}} 174.9\right)$, and one $\mathrm{sp}^{2}$ quaternary carbon signal $\left(\delta_{\mathrm{C}}\right.$ 153.2). The sequential COSY correlations from $\mathrm{H}_{2}-7\left(\delta_{\mathrm{H}} 4.03\right)$ through $\mathrm{H}_{2}-9\left(\delta_{\mathrm{H}} 2.36\right)$ combined with the HMBC correlation from $\mathrm{H}_{2}-8$ and $\mathrm{H}_{2}-9$ to $\mathrm{C}-10$ ( $\left.\delta_{\mathrm{C}} 174.9\right)$ indicated a butyric acid fragment. The COSY correlations from H-5 $\left(\delta_{\mathrm{H}} 6.31\right)$ to H-6 $\left(\delta_{\mathrm{H}} 7.53\right)$, together with the HMBC correlations from $\mathrm{H}_{3}-11\left(\delta_{\mathrm{H}} 2.25\right)$ to $\mathrm{C}-3\left(\delta_{\mathrm{C}} 117.8\right), \mathrm{C}-4\left(\delta_{\mathrm{C}}\right.$ $153.2)$, and $\mathrm{C}-5\left(\delta_{\mathrm{C}} 109.8\right)$, from $\mathrm{H}-3\left(\delta_{\mathrm{H}} 6.40\right)$ and $\mathrm{H}-6$ to $\mathrm{C}-2$ $\left(\delta_{\mathrm{C}} 163.3\right)$, and from $\mathrm{H}-5$ to $\mathrm{C}-3$ displayed a 4-methylpyridin$2(1 H)$-one fragment. Finally, the key HMBC correlations from $\mathrm{H}_{2}-7$ to C-2 and C-6 $\left(\delta_{\mathrm{C}} 137.4\right)$ connected above two fragments. Thus, the chemical structure of compound $\mathbf{4}$ was identified as shown in Figure 1 and named as cladoslide C.

The chemical structures of the previously reported $\mathrm{N}$-acetyl$\beta$-oxotryptamine (5) (Martínez-Luis et al., 2012), (4S,5S,11R)-isocladospolide B (6) (Reddy et al., 2012), (4S,5S,11S)-iso-cladospolide B (7) (Reddy et al., 2012), and (4R,5S,11R)-iso-cladospolide B (8) (Franck, et al., 2001) were identified by comparison of their spectroscopic data (see Supplementary Tables S1, S2 in Supplementary Material) with those in the literature.

Compounds $\mathbf{1}$ and $\mathbf{2}$ were postulated to be produced biogenetically from the polyketide pathway. Condensation and redox reaction between one malony $\mathrm{CoA}$ unit and five acetyl-CoA units formed intermediate (A), which further underwent methylation to form compound $\mathbf{1}$. Then, $\mathbf{1}$ underwent esterification to afford 2 (Figure 4). 


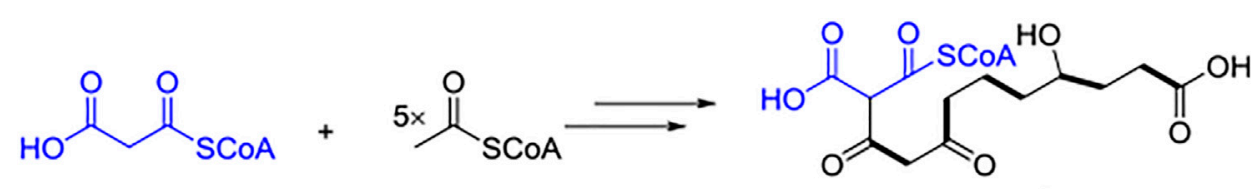

A

methylation<smiles>CC(O)(CCC(=O)O)CCc1cc(C(=O)O)ccc1O</smiles><smiles>CC(O)(CCC(=O)CC(=O)O)CC(=O)C(C(=O)O)C(=O)CCC(=O)O</smiles>

esterification<smiles>COC(=O)CCC(C)(O)CCc1cc(C(=O)O)ccc1O</smiles>

2

FIGURE 4 | Hypothetical biogenetic pathway of compounds $\mathbf{1}$ and $\mathbf{2}$.

\section{Biological Activity}

Compounds 1-3 and 5-8 were tested for their cytotoxicity against Hela, BEL-7402, K562, and SGC-7901 cell lines and a-glycosidase inhibitory activity (Table 3 ). Compound 1 showed cytotoxicity against the K562 cell line with an $\mathrm{IC}_{50}$ value of $13.10 \pm 0.08 \mu \mathrm{M}$. Besides, compounds 1 and 5 exhibited inhibitory activity against a-glycosidase with $\mathrm{IC}_{50}$ values of $0.32 \pm 0.01 \mathrm{mM}$ and $0.17 \pm 0.01 \mathrm{mM}$, respectively.

\section{CONCLUSION}

In conclusion, four new compounds (1-4) were isolated from the rice medium culture of the mangrove-derived fungus Cladosporium sp. HNWSW-1, along with four previously reported $\quad N$-acetyl- $\beta$-oxotryptamine $\quad(5), \quad(4 S, 5 S, 11 R)$-isocladospolide B (6), (4S,5S,11S)-iso-cladospolide B (7), and $(4 R, 5 S, 11 R)$-iso-cladospolide B (8). Compound 1 showed cytotoxicity against the $\mathrm{K} 562$ cell line with an $\mathrm{IC}_{50}$ value of $13.10 \pm 0.08 \mu \mathrm{M}$. Moreover, compounds $\mathbf{1}$ and $\mathbf{5}$ exhibited inhibitory activity against $\alpha$-glycosidase with $\mathrm{IC}_{50}$ values of $0.32 \pm 0.01 \mathrm{mM}$ and $0.17 \pm 0.01 \mathrm{mM}$, respectively.

\section{DATA AVAILABILITY STATEMENT}

The datasets presented in this study can be found in online repositories. The names of the repository/repositories and accession number(s) can be found in the article/ Supplementary Material.

\section{AUTHOR CONTRIBUTIONS}

PW, WM, and LG conceived and designed the experiments. XC, PW, CC, CG, and JY performed the experiments; PW and XC identified the structures of the compounds. PW and XC wrote the paper. WM, HD and FK reviewed the paper. All authors have approved the final version of the manuscript.

\section{FUNDING}

This research was funded by the Hainan Provincial Natural Science Foundation of China (No. 320QN335), Hainan Provincial Natural Science Foundation of China (No. 220RC702), and Financial Fund of the Ministry of Agriculture and Rural Affairs, P. R of China (No. NFZX 2023).

\section{SUPPLEMENTARY MATERIAL}

The Supplementary Material for this article can be found online at: https://www.frontiersin.org/articles/10.3389/fchem.2021.773703/ full\#supplementary-material 


\section{REFERENCES}

Bensch, K., Groenewald, J. Z., Braun, U., Dijksterhuis, J., de Jesús Yáñez-Morales, M., and Crous, P. W. (2015). Common but Different: The Expanding Realm of Cladosporium. Stud. Mycol. 82, 23-74. doi:10.1016/j.simyco.2015.10.001

Blunt, J. W., Carroll, A. R., Copp, B. R., Davis, R. A., Keyzers, R. A., and Prinsep, M. R. (2018). Marine Natural Products. Nat. Prod. Rep. 35, 8-53. doi:10.1039/ c7np00052a

Cao, L.-H., Zhang, W., Luo, J.-G., and Kong, L.-Y. (2012). Five New $\beta$-CarbolineType Alkaloids from Stellaria Dichotoma Var. Lanceolata. Hca 95, 1018-1025. doi:10.1002/hlca.201100485

Carroll, A. R., Copp, B. R., Davis, R. A., Keyzers, R. A., and Prinsep, M. R. (2019). Marine Natural Products. Nat. Prod. Rep. 36, 122-173. doi:10.1039/c8np00092a

Carroll, A. R., Copp, B. R., Davis, R. A., Keyzers, R. A., and Prinsep, M. R. (2020). Marine Natural Products. Nat. Prod. Rep. 37, 175-223. doi:10.1039/ C9NP00069K

Chen, Y.-F., Kuo, P.-C., Chan, H.-H., Kuo, I.-J., Lin, F.-W., Su, C.-R., et al. (2010). $\beta$-Carboline Alkaloids from Stellaria Dichotoma Var. Lanceolata and Their Anti-inflammatory Activity. J. Nat. Prod. 73, 1993-1998. doi:10.1021/ np1003627

Franck, X., Vaz Araujo, M. E., Jullian, J.-C., Hocquemiller, R., and Figadère, B. (2001). Synthesis and Structure Determination of Iso -cladospolide B. Tetrahedron Lett. 42, 2801-2803. doi:10.1016/s0040-4039(01)00323-9

Frelek, J., and Szczepek, W. J. (1999). [Rh2(OCOCF3)4] as an Auxiliary Chromophore in Chiroptical Studies on Steroidal Alcohols. Tetrahedron: Asymmetry 10, 1507-1520. doi:10.1016/S0957-4166(99)00115-9

Gerards, M., and Snatzke, G. (1990). Circular Dichroism, XCIII Determination of the Absolute Configuration of Alcohols, Olefins, Epoxides, and Ethers from the $\mathrm{CD}$ of Their "In Situ" Complexes with [Rh2(O2CCF3)4]. Tetrahedron: Asymmetry 1, 221-236. doi:10.1016/S0957-4166(00)86328-4

Huang, C., Chen, T., Yan, Z., Guo, H., Hou, X., Jiang, L., et al. (2019). Thiocladospolide E and Cladospamide A, Novel 12-membered Macrolide and Macrolide Lactam from Mangrove Endophytic Fungus Cladosporium Sp. SCNU-F0001. Fitoterapia 137, 104246. doi:10.1016/j.fitote.2019.104246

Ma, K., Han, J. J., Bao, L., Wei, T. Z., and Liu, H. W. (2014). Two Sarcoviolins with Antioxidative and a-glucosidaseinhibitory Activity from the Edible Mushroom Sarcodon Leucopus Collected in Tibet. J. Nat. Prod. 77, 942-947. doi:10.1021/ np401026b

Marfey, P. (1984). Determination ofD-Amino Acids. II. Use of a Bifunctional Reagent, 1,5-Difluoro-2,4-Dinitrobenzene. Carlsberg Res. Commun. 49, 591-596. doi:10.1007/BF02908688

Martínez-Luis, S., Gómez, J. F., Spadafora, C., Guzmán, H. M., and Gutiérrez, M. (2012). Antitrypanosomal Alkaloids from the marine Bacterium Bacillus Pumilus. Molecules 17, 11146-11155. doi:10.3390/molecules170911146
Mosmann, T. (1983). Rapid Colorimetric Assay for Cellular Growth and Survival: Application to Proliferation and Cytotoxicity Assays. J. Immunol. Methods 65, 55-63. doi:10.1016/0022-1759(83)90303-4

Peng, J., Lin, T., Wang, W., Xin, Z., Zhu, T., Gu, Q., et al. (2013). Antiviral Alkaloids Produced by the Mangrove-Derived Fungus Cladosporium Sp. PJX-41. J. Nat. Prod. 76, 1133-1140. doi:10.1021/np400200k

Reddy, C., Rao, N., Sujitha, P., and Kumar, C. (2012). Protecting Group-free Syntheses of $(4 S, 5 S, 11 R)$ - and $(4 S, 5 S, 11 S)$-Iso-Cladospolide B and Their Biological Evaluation. Synthesis 44, 1663-1666. doi:10.1055/s-0031-1290986

Wang, P., Cui, Y., Cai, C., Chen, H., Dai, Y., Chen, P., et al. (2019). Two New Succinimide Derivatives Cladosporitins A and B from the Mangrove-Derived Fungus Cladosporium Sp. HNWSW-1. Mar. Drugs 17, 4. doi:10.3390/ md17010004

Wang, P., Xi, L., Liu, P., Wang, Y., Wang, W., Huang, Y., et al. (2013). Diketopiperazine Derivatives from the marine-derived Actinomycete Streptomyces Sp. FXJ7.328. Mar. Drugs 11, 1035-1049. doi:10.3390/ md11041035

Zhang, F.-Z., Li, X.-M., Li, X., Yang, S.-Q., Meng, L.-H., and Wang, B.-G. (2019). Polyketides from the Mangrove-Derived Endophytic Fungus Cladosporium Cladosporioides. Mar. Drugs 17, 296. doi:10.3390/ md17050296

Zhang, F., Zhou, L., Kong, F., Ma, Q., Xie, Q., Li, J., et al. (2020). Altertoxins with Quorum Sensing Inhibitory Activities from the Marine-Derived Fungus Cladosporium Sp. KFD33. Mar. Drugs 18, 67. doi:10.3390/md18010067

Zhu, G., Kong, F., Wang, Y., Fu, P., and Zhu, W. (2018). Cladodionen, a Cytotoxic Hybrid Polyketide from the marine-derived Cladosporium Sp. OUCMDZ1635. Mar. Drugs 16, 71. doi:10.3390/md16020071

Conflict of Interest: The authors declare that the research was conducted in the absence of any commercial or financial relationships that could be construed as a potential conflict of interest.

Publisher's Note: All claims expressed in this article are solely those of the authors and do not necessarily represent those of their affiliated organizations, or those of the publisher, the editors, and the reviewers. Any product that may be evaluated in this article, or claim that may be made by its manufacturer, is not guaranteed or endorsed by the publisher.

Copyright $\odot 2021$ Cao, Guo, Cai, Kong, Yuan, Gai, Dai, Wang and Mei. This is an open-access article distributed under the terms of the Creative Commons Attribution License (CC BY). The use, distribution or reproduction in other forums is permitted, provided the original author(s) and the copyright owner(s) are credited and that the original publication in this journal is cited, in accordance with accepted academic practice. No use, distribution or reproduction is permitted which does not comply with these terms. 